\title{
ELT instructors' attitudes towards the use of Blended Learning in tertiary level English language programs ${ }^{1}$
}

\author{
Şaban Çepik ${ }^{2}$ \\ Kemal Gönen ${ }^{3}$ \\ Mustafa Kemal Sazak ${ }^{4}$
}

\begin{abstract}
The aim of this study is to find the attitudes of language instructors towards blended learning at English Language Program of a foundation university, and to find out the nature of Schoology, a learning management system, for blended learning purposes. The participants were 35 English language instructors working at the foundation university in Turkey. A questionnaire developed by Moukali (2012) was used as a data collection tool in this study. The findings revealed that the English language instructors working for tertiary level English Language Program have a positive attitude towards blended learning. On the other hand, the opinions of the participants to make blended learning more successful in language teaching and learning environments were reflected comprehensively in the study.
\end{abstract}

Keywords: Blended Learning; Teaching/Learning Methods; Learning Management Systems; Attitudes of Teachers.

\section{Introduction}

\subsection{Blended Learning in an ELT Context}

As technology is seen in every part of life, e-learning has always been an important part in English language teaching. This shift to technology has brought many definitions for some terms such as online learning, distance learning, or e-learning. One of them is called "blended learning". According to Singh and Reed (2001), "blended learning can be described as a learning program where more than one delivery mode is being used with the objective of optimizing the learning outcome and cost of program delivery". In the same study, Singh and Reed (2001) point out that "the original use of the phrase 'Blended Learning' was often associated with simply linking traditional classroom training to e-learning activities."

The origin of the first example of blended learning is unknown. However, according to Marsh (2013), blended learning "first appeared around 2000, but just as the practice of blending learning is not a new way of teaching, neither is it a single method of learning, nor is the practice of

\footnotetext{
1 Paper has been presented on "International Lifelong Learning and Leadership for all" conference.

2 Prof. Dr., Zirve University, Faculty of Education, ELT Department, saban.cepik@zirve.edu.tr

${ }^{3}$ Ph.D. c., Zirve University, School of Foreign Languages, English Language Program, kemal.gonen@zirve.edu.tr

${ }^{4}$ M.A., Zirve University, School of Foreign Languages, English Language Program,, mustafa.sazak@,zirve.edu.tr
} 

level English language programs. International Journal of Human Sciences, 13(1), 1715-1730. doi:10.14687/ijhs.v13i1.3719

blending different learning approaches, strategies, and opportunities unfamiliar to teachers." The effectiveness of blended learning depends on the environment of the institutions that are using it. There are many factors affecting the quality of blended learning. Some of them are, strong Internet connection, quality of instructional methods, content presentation, effective use of time, and support provided to the learners. If one of these factors lacks in the environment of blended learning, the quality of education given may decrease.

At Zirve University, every teacher and student gets a MacBook Pro or MacBook Air computer. These computers are provided by Zirve University for free. There are lots of online facilities provided to the teachers and students. Some of them are wikis, blogs, and e-mail services. However at School of Foreign Languages (SFL) at Zirve University, the situation is a bit different. In addition to the facilities provided to the whole school, the students of SFL are provided with an online learning platform called "Schoology".

Schoology, in its website, is described as "an online learning, classroom management, and social networking platform that improves learning through better communication, collaboration, and increased access to curriculum and supplemental content." Each student has a Schoology account and they easily access to the materials provided by their teachers, and the teachers keep their grades on Schoology.

As the technology develops, virtual classrooms have been used by many institutions in Turkey in order to catch up with the technology. At Zirve University, School of Foreign Languages, the teachers and the students did not use any of the online learning platforms before. The instructors started using Schoology as the online learning platform in Main Course, Applied Language Study, Reading \& Writing, and Listening \& Speaking classes in 2012/2013. Even though the teachers and the students use Schoology as an online learning platform, no feedback from the teachers and students has been received so far. In accordance with this, the effectiveness of this platform is unknown in my context.

\subsection{What is Blended Learning?}

Blended learning has been defined in a variety of ways. As Sharma and Barett (2007) point out, blended learning harmonizes technology and a face-to-face classroom component to teach a language. In another study, Copping and Mellett (2004) mention that blended learning includes the combination of "IT-based (Web and CD-ROM delivery) and problem-based learning [PBL] strategies with an existing paper-based program of study". Accordingly, technology, together with the components of class, plays an important role in blended learning. Similarly, Xian Tang and Qun Pan (2008) state that blended learning is facilitated by combining different elements of learning such as delivery, models of teaching, and learning styles with the transparent communication of all ingredients of the course.

For Ellis and Calvo (2006), blended learning is a "systematic mix of e-leaning and learning in face-to-face contexts, in which coherence across the two contexts from a student perspective is achieved by focusing on the same intended learning outcomes". According to John Merrow (2012), "blended learning is some mix of traditional classroom instruction (which in itself varies considerably) and instruction mediated by technology" and he continues, "the latter can be one student with a tablet or laptop, or small groups of kids working together on devices" (ibid.). Lynch and Dembo (2004) pointed out that blended education is a form of distributed education, and "distributed education represents an eclectic blend of technologies and modalities to enable both synchronous (real time) and asynchronous (anytime) teacher-learner and learner-learner interactions 
Çepik, Ş., Gönen, K., \& Sazak, M. K. (2016). ELT instructors' attitudes towards the use of Blended Learning in tertiary level English language programs. International Journal of Human Sciences, 13(1), 1715-1730. doi:10.14687/ijhs.v13i1.3719

in a single course or program" According to Mohammad (2009), "blended learning is a powerful method of the learning and teaching process that successfully mixes the best features of both traditional and electronic learning in order to promote active independent learning and reduce class room time" (p. 299). Natasa Hoic-Bozic, Vedran Mornar, and Ivica Boticki (2009) defines blended learning as "learning based on various combinations of classical face-to-face lectures, learning over the Internet and learning supported by other technologies, aimed at creating the most efficient learning environment. Blended Learning in ELT

According to Sharma (2007), "an increasing number of language schools are integrating technology into their courses. Yet implementing blended learning is not straightforward. It involves a number of critical decisions and consultation among students, teachers, directors of studies and the school management." In the same article, Sharma (2007) points out five practical examples about how to follow blended learning guidelines in a lesson level:

1. A teacher gives a presentation by discussing the topic. Then with the help of CDROM, he/ she allows students to practice phrases that he/she previously taught.

2. In the classroom, the teacher wants students to create a text online. The revision of the text is done remotely. Then the teacher reads the text and uses the lesson to give feedback to the students.

3. A class creates an audio file. The students post the result to the website of the class and search authentic listening files on the Internet. In this way, students are motivated to download more audio files to their MP3 players.

4. A small group of teachers download Moodle software and they are now able to support their next course by using the VLE (Virtual Learning Environment) to communicate with their students.

5. A teacher creates a blog in order to give feedback to the students. The feedback he/she posts includes links to audio files of words that the students have difficulty in pronouncing.

To balance traditional approaches and technology, Sharma and Barrett (2007) suggest four principles. These include separating the role of the teacher and the role of the technology; teaching in a principled way; using technology to complement Face to Face teaching; and by quoting "it's not so much the program, more what you do with it" (Jones, 1986), indicating the different uses of a CD-ROM.

\subsection{Research Questions}

This study addresses the following research questions:

1. What is the nature of using Schoology for blended learning purposes?

2. What are the attitudes of ELT instructors toward blended learning at Zirve University?

\section{Methodology, Setting, and Participants}

This study was conducted at Zirve University, School of Foreign Languages (SFL). At School of Foreign Languages, there are 4 quarters in an academic year, and four levels in English education: Elementary level (A), pre-intermediate level (B), intermediate level (C), and upperintermediate level (D). Each level takes approximately eight weeks to complete. 
Çepik, Ş., Gönen, K., \& Sazak, M. K. (2016). ELT instructors' attitudes towards the use of Blended Learning in tertiary level English language programs. International Journal of Human Sciences, 13(1), 1715-1730. doi:10.14687/ijhs.v13i1.3719

The participants of this study were 35 randomly chosen ELT instructors, teaching random skills. Among these 35 participants, 63\% were male, while 37\% were female. Among the participants, 3\% have 1-2 years experience, $43 \%$ have $2-4$ years experience, 31\% have 4-6 years experience, $6 \%$ have 6-8 years experience, and finally $17 \%$ have $8-10$ or more years of experience.

This information shows that most of the participants are experienced in teaching English. Fourteen percent of the participants were 21-24 years old, while $63 \%$ were $25-29,11 \%$ were $30-34$, $6 \%$ were $35-39,3 \%$ are $40-44$, and $3 \%$ were 55 or more years old.

\subsection{Data Collection Instruments}

In this study, the data collection instrument used is a survey adapted from a Ph.D. thesis by Khalid Hussain Moukali (2012).

Table 1.

Characteristics of the Survey Used in This Study

\begin{tabular}{|l|l|l|}
\hline Subscales & Number of Items \\
\hline Demographic Information & \\
\hline Attitudes toward Blended Learning & \\
\hline Barriers that Affect the Adoption of Blended Learning & \\
\hline Incentives of Blended Learning & \\
\hline \hline \\
\hline Open-Ended Questions
\end{tabular}

\subsection{Data Analysis}

The researcher aimed to find the attitudes of ELT instructors toward blended learning at Zirve University. The researcher used descriptive statistics to conduct the analysis. According to Boeree (2005), descriptive statistics "are ways of summarizing large sets of quantitative (numerical) information". The questionnaire was prepared by using Google Docs and sent via e-mail to 35 randomly chosen instructors. All questions were written in English, and the results were collected using Google Docs. The answers were processed using Microsoft Excel and presented in percentages for each question.

\subsection{Data Collection Environment: Schoology}

Schoology (www.schoology.com) is an online learning, classroom management, and social networking platform that improves learning through communication, collaboration, and access to curriculum and supplemental content. Schoology is a learning management system (LMS), and it includes features like attendance records, online gradebook, assignments, test and quizzes, and online dropbox for homework. It also includes instructional tools, administrative tools, and course 
Çepik, Ş., Gönen, K., \& Sazak, M. K. (2016). ELT instructors' attitudes towards the use of Blended Learning in tertiary level English language programs. International Journal of Human Sciences, 13(1), 1715-1730. doi:10.14687/ijhs.v13i1.3719

delivery tools. When compared to the other free and paid learning management systems, Schoology is more likely to be user-friendly and it has more social features than the other systems, which allow students to interact with their teachers and peers (schoology, 2013).

There are three types of login screen of Schoology: instructor, student, and parent. In addition to these users, there is an administrator who can create and edit courses, groups, users, calendar, and system settings. Instructors can add students to their virtual classes, assign homework, and grade their students. They can send either bulk messages to their classrooms or individual messages to their students. They can also create their own blogs on Schoology and share status updates on their virtual classrooms. Students don't have privileges like sending messages to the other students or seeing the grades of their friends. They can communicate with their teachers whenever they want. They cannot share status updates and they don't have blogs, but they can make comments on status updates, discussion circles, or polls. Another type of user is parents. Parents can see the grades and attendance records of their students, and they can send messages to the instructors of their children. For Zirve School of Foreign Languages the parent login is not used since this feature is not suitable for university level students.

Schoology uses an access code feature to enroll students into classes or groups. If a student wants to enroll in a class, he/she needs to know the access code of that classroom. Teachers do not have to use access codes because they are assigned as admins to their classrooms by the administrator of the system. Access codes are delivered to the students by their teachers after the start of the each term.

\subsection{Data Collection Process}

After the required permission was given by the official research ethics committee of Zirve University, the project started in August 20, and continued until the second term of the 2012- 2013 Academic Year. The project took approximately 6 months to complete. There were several stages in conducting the project.

\subsection{Training Sessions}

At the beginning of September, the researcher started giving training sessions to the administrators and instructors. Trainings were divided into 2 different sessions because of the large number of instructors. Before the beginning of the term, the instructors had 3 weeks to discover the features of Schoology, and ask questions to the researcher.

\section{RESULTS AND DISCUSSION}

\subsection{Findings from the Demographic Information}

In this study, 35 ELT instructors working at Zirve University took the questionnaire. Among these 35 participants, 22 were male, and 13 were female. The participants are mostly from the age group 25-29 (63\%) years, and work experience group 2-4 years (46\%). Since this study is related to the use of technology in ELT classes, questions related to the use of technology in language teaching were asked. According to the results of the demographic information part of the questionnaire, $46 \%$ of the participants have 2-4 years of experience using Internet-based learning. This group is followed by 0-2 years of experience (37\%), 4-6 years of experience $(9 \%), 6-8$ years of experience $(6 \%)$, and 8-10 and more years of experience $(3 \%)$, respectively. When the item related 
Çepik, Ş., Gönen, K., \& Sazak, M. K. (2016). ELT instructors' attitudes towards the use of Blended Learning in tertiary level English language programs. International Journal of Human Sciences, 13(1), 1715-1730. doi:10.14687/ijhs.v13i1.3719

to previous personal experience with blended learning is analyzed, $51 \%$ of the participants have previous experience as an instructor, $23 \%$ of them have no previous experience with blended learning, 14\% have previous experience as a student, and 11\% have experiences both as a student and instructor. The results of this item are a bit surprising because even though the description of blended learning was given clearly at the beginning of the survey, and Zirve University has been using Schoology as a learning management system (LMS) for 6 months, 23\% of the respondents indicated that they did not have previous experience with blended learning. The reason for this might be that they skipped reading the explanation of blended learning. In another item, the participants were asked to indicate their level of experience in a scale from the poorest level 1 to the strongest level 10, and most of the participants ( $\% 29)$ marked level 8 , while $26 \%$ of them marked level 6, which was followed by the levels $7(20 \%), 10(11 \%), 5(9 \%), 9(3 \%)$, and $3(3 \%)$. The final demographic item was about choosing the LMS that they would evaluate through the questionnaire, and all of the instructors chose Schoology as LMS.

\subsection{Findings from the Questionnaire}

In order to analyze the items related to the different subjects, this section is grouped into 4 main categories: Experience with Educational Technologies, Attitudes toward Blended Learning, Barriers that Affect the Adoption of Blended Learning, and finally. Incentives of

Blended Learning. Under each category, the participants were asked to respond to 5-point Likert scale items.

\subsection{Findings on the Experience with Educational Technologies}

The purpose of this category is to find how familiar the participants are with educational technologies which is defined by Association for Educational Communications and Technology (AECT) Definition and Terminology Committee (2004) as "the study and ethical practice of facilitating learning and improving performance by creating, using, and managing appropriate technological processes and resources" (p. 1). Under this category, the participants were asked to respond to 7 items. In Table 2, percentages and frequencies of the participants' responses are given.

The first item, "Learning Management Systems" is the most important item in this category because it is the closest item to the aim of this study. When we look at the first item, we can say that most of the teachers (40\%) have average experience in Learning Management Systems. In section 4.2 , the researcher found that $23 \%$ of the participants indicated that they do not have a previous experience with blended learning, but in the first item, none of the participants responded "No Experience". This may be a conflict because Learning Management System is a tool for blended learning. The number of the participants responded "Somewhat Good" is 13 (37\%). Only 6 participants $(17 \%)$ responded "Very Good" for the first item.

Most of the participants (43\%) indicated that they are somewhat good at using a word processor (e g. Microsoft Word, Pages etc). Thirty-seven percent of the participants responded "Very Good" to this item, and none responded "No Experience". These responses show that the participants are good at using a word processor, which is an expected result since the instructors at Zirve University are using word processors effectively in electronic correspondence, and preparing worksheets and homework on computers.

For the third item, Spreadsheet Program (e g. Microsoft Excel, Numbers, etc.), 46\% of the participants responded "Good" while $11 \%$ of them considered themselves to be very good at using a spreadsheet programs. Unlike the items $1,2,4,5$, and 6 , in this item, the participants responded 
Çepik, Ş., Gönen, K., \& Sazak, M. K. (2016). ELT instructors' attitudes towards the use of Blended Learning in tertiary level English language programs. International Journal of Human Sciences, 13(1), 1715-1730. doi:10.14687/ijhs.v13i1.3719

"No Experience" in using Spreadsheet Program. This response is not surprising because spreadsheet programs are generally used for math calculations and numeric data, and ELT instructors generally do not need to use spreadsheet programs at Zirve University.

Table 2 .

Responses to the Items Related to the "Experience with Educational Technologies"

\begin{tabular}{|c|c|c|c|c|c|c|c|c|c|c|}
\hline & \multicolumn{2}{|c|}{$\begin{array}{c}\text { No } \\
\text { Experience }\end{array}$} & \multicolumn{2}{|c|}{ Poor } & \multicolumn{2}{|c|}{ Average } & \multicolumn{2}{|c|}{$\begin{array}{r}\text { Somewhat } \\
\text { Good }\end{array}$} & \multicolumn{2}{|c|}{ Very Good } \\
\hline & f & $\%$ & f & $\%$ & f & $\%$ & f & $\%$ & f & $\%$ \\
\hline $\begin{array}{l}\text { Learning Management } \\
\text { Systems }\end{array}$ & 0 & 0 & 2 & 6 & 14 & 40 & 13 & 37 & 6 & 17 \\
\hline Word Processor & 0 & 0 & 1 & 3 & 6 & 17 & 15 & 43 & 13 & 37 \\
\hline Spreadsheet Program & 4 & 11 & 5 & 14 & 6 & 17 & 16 & 46 & 4 & 11 \\
\hline Presentation Program & 0 & 0 & 0 & 0 & 1 & 3 & 20 & 57 & 14 & 40 \\
\hline E-mail Programs & 0 & 0 & 1 & 3 & 3 & 9 & 11 & 31 & 20 & 57 \\
\hline Web Search Engines & 0 & $\theta$ & 0 & 0 & 2 & 6 & 14 & 40 & 19 & 54 \\
\hline Smart Board & 21 & 60 & 5 & 14 & 3 & 9 & 5 & 14 & 1 & 3 \\
\hline
\end{tabular}

The number of respondents responding "Somewhat Good" for the item "Presentation Program" is $57 \%$. This is followed by $40 \%$ "very good". This is not a surprising result because ELT instructors at Zirve University use presentation programs (e.g. Microsoft PowerPoint, Keynote, etc.) while preparing visual activities and slideshows for their classes. For the fifth item, $57 \%$ of the participants marked "Very Good" and 31\% of them responded "Somewhat Good". This was an expected result because at Zirve University, instructors are provided with MacBook computers, and they use an application called Mail.app for their correspondence purposes.

Nineteen percent of the participants responded "Very Good" to item 6, Web Search Engines (e g. Google, Yahoo, etc.), while 40\% of them responded "Good". This result was also expected because most of the people use a web search engine as a default homepage for their browsers. Most of the participants (60\%) responded "No Experience" to the item 7, Smart Board. However 3\% of them responded "Very Good". The researcher assumes this result is because the definition of Smart Board was not given at the questionnaire. Another reason might be that there is no Smart Board at Zirve University, and Smart Boards have become popular in Turkey recent years.

\subsection{Findings on the Attitudes toward Blended Learning}

This category is the most helpful category to answer the research question "What are the attitudes of ELT instructors toward blended learning at Zirve University". The researcher aimed to find out the beliefs, attitudes, and thoughts of the participants about blended learning. There are 7 items under this category, and the responses are shown in Table 3. 
Çepik, Ş., Gönen, K., \& Sazak, M. K. (2016). ELT instructors' attitudes towards the use of Blended Learning in tertiary level English language programs. International Journal of Human Sciences, 13(1), 1715-1730. doi:10.14687/ijhs.v13i1.3719

The first item of this category is about the support of blended learning in collaborative learning. Most of the participants $(60 \%)$ agree that blended learning approach supports collaborative learning while $11 \%$ of them strongly agree this item. While answering this item, most of the respondents might have thought that the assignments and homework given through Schoology are solved in groups by the students. However, $3 \%$ of the participants responded "Strongly Disagree", and 14\% of them responded "Disagree". The reason for the negative responses to this item might be that on Schoology, none of the teachers have assigned group work to the students so far. This fact might be considered while answering this item.

Table 3.

Responses to the Items Related to the Attitudes toward Blended Learning

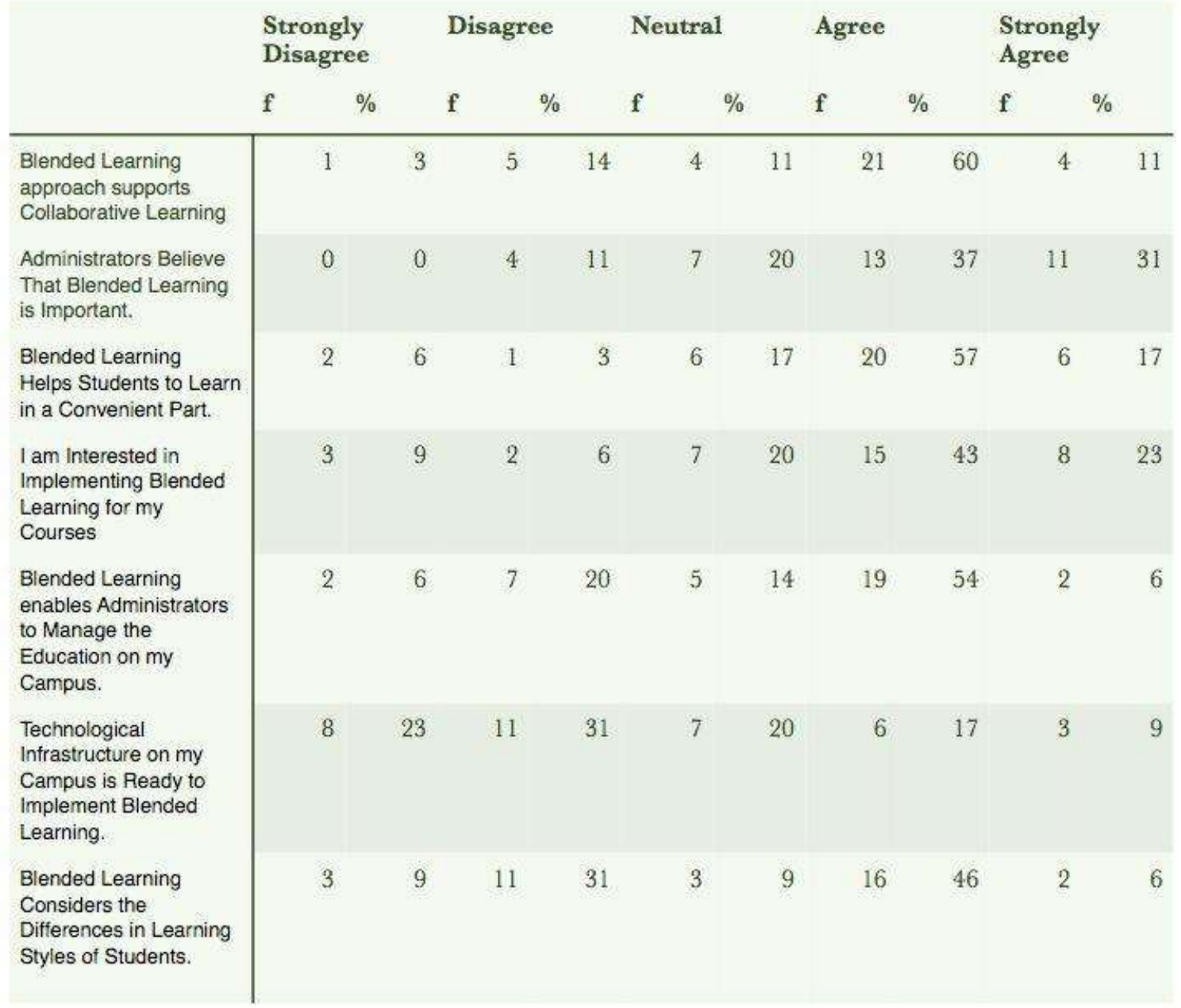

The second item was unclear for the respondents to respond because in the process of blended learning experiences at Zirve University, the instructors didn't hear any positive or negative comments from the administrators about the use of Schoology. Most of the participants (37\%) responded "Agree". In addition to this, the researcher didn't need to ask specific questions to the administrators about the implementation of blended learning because this study covers the overall attitudes of ELT teachers toward blended learning at Zirve University. There is no specific group of instructors (e g. administrators, skill coordinators) targeted in this study. 
Çepik, S.., Gönen, K., \& Sazak, M. K. (2016). ELT instructors' attitudes towards the use of Blended Learning in tertiary level English language programs. International Journal of Human Sciences, 13(1), 1715-1730. doi:10.14687/ijhs.v13i1.3719

For the item 3, Blended Learning Helps Students to Learn in a Convenient Way, most of the participants (57\%) responded "Agree". 17\% of the participants responded "Strongly Agree". For the positive responses, the features of Schoology (e g. online homework, gradebook, materials, etc.) might have been reasons. Forty-three percent of the participants responded "Agree" to the item 4. $23 \%$ of them marked "Strongly Agree" while 20\% of them were neutral. However, $15 \%$ of the participants responded negatively to this item. The instructors who are interested in implementing blended learning for their courses should have seen the benefits of blended learning in teaching (e g. material sharing, communication with students, grading through Schoology, etc.)

Most of the participants (54\%) responded "Agree" to the item 5, Blended Learning Enables Administrators to Manage the Education on my Campus. The reason for this might be that both the administrators and the skill coordinators were periodically checking the gradebook and the online materials of the online classes. When a category is missing on one of the online classrooms gradebook, skill coordinators warn the instructor responsible for maintaining the mentioned online classroom. Another reason for the positive responses for this item can be that skill coordinators are responsible for the delivery of online homework for the online classrooms, and this might be regarded as a management by the administrators. When the item Technological Infrastructure on my Campus is Ready to Implement Blended Learning was asked, $31 \%$ of the respondents responded "Disagree", which is followed 23\% who chose "Strongly Disagree". The slow Internet at Zirve University is the primary reason for the negative responses. For the instructors who responded "Agree" and "Strongly Agree" (9 in total, 26\%) the reason might be the computers delivered to the students and the instructors. Forty-six percent of the participants responded "Agree" to the item 7, which is the last item of this category. Thirty-one percent of the instructors responded "Disagree" to this item.

These two results are close to each other. Some participants might have regarded the ability of using technology while answering "Disagree" to this item, while the others might have supposed that blended learning offers different styles of learning (e.g. visual learning, auditory learning, etc.).

For the second item I don't have enough technological support, $43 \%$ of the participants responded "Disagree" and 29\% of them responded "Strongly Disagree". Eleven percent of the participants agree to this item. The percentage of participants who chose the answer "Strongly Agree" is 6\%. The researcher provided all the technical support during the blended learning experience. Those who selected "Strongly Agree" and "Agree" responses might be the ones who didn't ask for technical help during the blended learning process.

The third item is similar to the second item. It is about technological training. Most of the participants (37\%) responded "Agree" to this item. Before the implementation of blended learning, the researcher gave workshops and seminars about the use of Schoology. The respondents might have thought technological training in general, not only Schoology because the researcher didn't give any technological training about any subject other than Schoology.

Another reason for this may be that some instructors didn't attend the workshops at the beginning of blended learning process. Thirty-one percent of the participants agreed that the Internet is not available on the campus while $26 \%$ of them strongly disagreed to this item. While answering this item, some participants may have though this item applied only to instructors, while others may have thought that this item is related to both the instructors and the students. While connecting to the Internet, the students are dependent only on Wi-Fi, but the instructors have a chance to connect to the Internet by using an Ethernet cable when Wi-Fi is not available, or the wireless Internet signal is poor. Most of the participants responded "Strongly Agree" to the item 5. 
Çepik, Ş., Gönen, K., \& Sazak, M. K. (2016). ELT instructors' attitudes towards the use of Blended Learning in tertiary level English language programs. International Journal of Human Sciences, 13(1), 1715-1730. doi:10.14687/ijhs.v13i1.3719

Six percent of them chose "Agree", and 2\% answered negative. As all the instructors and students have MacBook computers delivered to them by Zirve University, it is hard to understand the responses of respondents who disagree with this item. Most of the participants $(69 \%)$ think that blended learning increases their workload while $12 \%$ of them think the opposite. During the blended learning process, this item was the highest complaint from the instructors.

Table 4

Responses to the Items Related to the "Barriers That Affect the Adoption of Blended Learning"

\begin{tabular}{|c|c|c|c|c|c|c|c|c|c|c|}
\hline & \multicolumn{2}{|c|}{$\begin{array}{l}\text { Strongly } \\
\text { Disagree }\end{array}$} & \multicolumn{2}{|c|}{ Disagree } & \multicolumn{2}{|c|}{ Neutral } & \multicolumn{2}{|c|}{ Agree } & \multicolumn{2}{|c|}{$\begin{array}{l}\text { Strongly } \\
\text { Agree }\end{array}$} \\
\hline & f & $\%$ & f & $\%$ & f & $\%$ & $f$ & $\%$ & f & $\%$ \\
\hline I don't have technology experience. & 20 & 57 & 10 & 29 & 2 & 6 & 0 & 0 & 3 & 9 \\
\hline I don't have technological support. & 10 & 29 & 15 & 43 & 4 & 11 & 4 & 11 & 2 & 6 \\
\hline I don't have enough technological training. & 8 & 23 & 9 & 26 & 3 & 9 & 13 & 37 & 2 & 6 \\
\hline Internet is not available on my campus & 9 & 26 & 3 & 9 & 8 & 23 & 11 & 31 & 4 & 11 \\
\hline Computers are not available on my campus. & 29 & 83 & 2 & 6 & 0 & 0 & 3 & 9 & 1 & 3 \\
\hline Blended learning increases my workload & 2 & 6 & 2 & 6 & 7 & 20 & 14 & 40 & 10 & 29 \\
\hline My colleagues don't like blended learning. & 1 & 3 & 5 & 14 & 10 & 29 & 13 & 37 & 6 & 17 \\
\hline Blended learning reduces my contact with students. & 15 & 43 & 11 & 31 & 5 & 14 & 3 & 9 & 1 & 3 \\
\hline $\begin{array}{l}\text { My campus uses a poor learning management } \\
\text { system }\end{array}$ & 12 & 34 & 12 & 34 & 6 & 17 & 5 & 14 & 0 & 0 \\
\hline $\begin{array}{l}\text { My students don't have enough technology } \\
\text { experience. }\end{array}$ & 1 & 3 & 4 & 11 & 4 & 11 & 15 & 43 & 11 & 31 \\
\hline My students don't have Internet at home. & 3 & 9 & 2 & 6 & 10 & 29 & 15 & 43 & 5 & 14 \\
\hline
\end{tabular}

Entering weekly grades to gradebook, delivering online homework and assignments, and uploading in-class materials to Schoology might have been considered an extra workload by the instructors. Most of the respondents (37\%) responded "Agree" to the item 7, "My Colleagues Don't Like Blended Learning". Twenty-nine percent of them were neutral to this item, while 17\% responded "Strongly Agree". The reason for these answers might be because of the conversations among the instructors about extra workload brought on by Schoology. The communication feature available through Schoology is another unique feature that instructors like. When an instructor wants, he/she can send an e-mail to the whole class, or a specific student. Forty-three percent $(43 \%)$ of the participants responded "Strongly Agree" to the item 8, Blended Learning Reduces my Contact with Students and $31 \%$ of them responded "Agree". 12\% of the participants who disagreed to this item may not have known how to communicate with their students through Schoology. The item 9 is about the quality of the LMS used at Zirve University. As it is stated in this study, the LMS for blended learning purpose at Zirve University is Schoology. Thirty-four percent $(34 \%)$ of the instructors responded "Strongly Disagree", and 34\% of them responded "Disagree". The benefits offered by Schoology are more than any other current LMS. 
Çepik, S.., Gönen, K., \& Sazak, M. K. (2016). ELT instructors' attitudes towards the use of Blended Learning in tertiary level English language programs. International Journal of Human Sciences, 13(1), 1715-1730. doi:10.14687/ijhs.v13i1.3719

Most of the participants (43\%) agreed that their students do not have enough technological experience. During the blended learning process, no workshop or training was given to the students by the researcher. The students learned the use of Schoology from their instructors. Any workshop about the use of technology was not given either.

The students who don't have Internet at home suffered a lot from online homework and assignments. They complained to their teachers and the researcher. They were asked to do their homework at school, by connecting to the Wi-Fi at the campus, or advised to buy a mobile Internet modem. By looking at these complaints, most of the participants (43\%) responded "Agree" to the item 11 . Twenty-nine percent were neutral to this item while $14 \%$ strongly agreed and $15 \%$ didn't agree.

\subsection{Findings on the Incentives of Blended Learning}

This category aims to find the results of the positive aspects brought by blended learning. There are 7 items under this category and the items are related to both the students and the instructors. The results of this category are given in Table 5 .

Table 5.

Responses to the Items Related to the Incentives of Blended Learning

\begin{tabular}{|c|c|c|c|c|c|c|c|c|c|c|c|c|}
\hline & \multicolumn{3}{|c|}{$\begin{array}{l}\text { Strongly } \\
\text { Disagree }\end{array}$} & \multicolumn{3}{|c|}{ Disagree } & \multicolumn{2}{|c|}{ Neutral } & \multicolumn{2}{|c|}{ Agree } & \multicolumn{2}{|c|}{$\begin{array}{l}\text { Strongly } \\
\text { Agree }\end{array}$} \\
\hline & f & $\%$ & & f & 9 & $\%$ & f & $\%$ & f & $\%$ & f & $\%$ \\
\hline $\begin{array}{l}\text { Blended learning facilitates the tracking of } \\
\text { student performance. }\end{array}$ & & 3 & 9 & & 2 & 6 & 5 & 14 & 13 & 37 & 12 & 34 \\
\hline $\begin{array}{l}\text { Blended learning makes better use of class } \\
\text { time. }\end{array}$ & & 1 & 3 & & 9 & 26 & 3 & 3 & 14 & 40 & 17 & 49 \\
\hline $\begin{array}{l}\text { Blended learning gives students access to } \\
\text { class materials at any time. }\end{array}$ & & 3 & 9 & & 0 & 0 & 1 & 3 & 14 & 40 & 18 & 51 \\
\hline $\begin{array}{l}\text { Blended learning gives students more media } \\
\text { resources. }\end{array}$ & & 1 & 3 & & 2 & 6 & 0 & 0 & 14 & 40 & 18 & 51 \\
\hline $\begin{array}{l}\text { Blended learning accommodates different } \\
\text { types of students and instructors. }\end{array}$ & & 1 & 3 & & 2 & 6 & 5 & 14 & 15 & 43 & 12 & 34 \\
\hline $\begin{array}{l}\text { Blended learning provides better } \\
\text { communication for students and instructors }\end{array}$ & & 2 & 6 & & 4 & 11 & 5 & 14 & 10 & 29 & 14 & 40 \\
\hline $\begin{array}{l}\text { Blended learning improves students and } \\
\text { instructors technological skills. }\end{array}$ & & 1 & 3 & & 0 & 0 & 7 & 20 & 15 & 43 & 12 & 34 \\
\hline
\end{tabular}

Through Schoology, instructors can track their students' progress. They can enter their students' grades on the online gradebook, they can make comments on the grades of the students, and they can give effective feedback to their students. Most of the participants (37\%) responded "Agree" to the item 1 in this category. 34\% of them responded "Strongly Agree". These results indicate that the teachers found Schoology's gradebook feature effective. For the item 2, Blended Learning Makes Better Use of Time, $40 \%$ of the instructors responded "Agree" while $26 \%$ of them responded "Disagree". For some teachers, using Schoology for blended learning purposes was an 
Çepik, Ş., Gönen, K., \& Sazak, M. K. (2016). ELT instructors' attitudes towards the use of Blended Learning in tertiary level English language programs. International Journal of Human Sciences, 13(1), 1715-1730. doi:10.14687/ijhs.v13i1.3719

effective way to give online assignments, and review the results easily. For some other teachers, online quizzes and assignments feature in Schoology was an extra burden, and teachers thought they could make better use of his/her time evaluating the papers of his/her students.

Item 3 is about accessing class materials at any time. Forty-nine percent of the participants responded "Strongly Disagree". 40\% of them responded "Agree" to this item. Only $9 \%$ of the participants responded "Strongly Disagree". A teacher can upload in-class materials to Schoology, and share them with his/her students. The students can access these materials at any time, without effort. Even though a workshop was given about how to share materials with the students, it is interesting to see 3 participants responding "Strongly Disagree" to this item.

Item 4 is similar to item 3 in the way of sharing media with the students. Schoology supports rich media types to be uploaded to its servers. For this item, most of the participants $(14 \%)$ responded "Strongly Agree", while 3\% of the participants disagree with this item.

Most of the participants $(77 \%)$ agreed to the item 5, Blended Learning Accommodates Different Types of Students and Instructors. Only $9 \%$ of the participants disagreed with this item.

There are different types of learners on Schoology, as well as different types of instructors in terms of age, sex, learning/teaching style, and experience. Forty percent of the participants responded "Strongly Agree" to item 6, while 11\% of them responded "Disagree", and 6\% of them strongly disagree. For some teachers at Zirve University, technology makes people asocial. For others, technology is a good means of reaching people easily. People who responded to this item positively are in the latter group.

Item 7 is about blended learning's contribution to the technological development of its implementers. Only 3\% of the participants responded "Strongly Disagree" to this item while most of the participants (43\%) responded "Agree", and 34\% of them responded "Strongly Agree".

\section{CONCLUSIONS}

\subsection{Research Question 1}

The first research question was issued in order to investigate the nature of using an LMS for blended learning purposes. The researcher aimed to find out whether the characteristic features of the chosen LMS software are in accordance with blended learning purposes. Thus, Schoology was chosen to conduct this study, and the following research question was asked:

What is the nature of using Schoology for blended learning purposes?

In order to find out an answer for this question, Schoology was used at School of Foreign Languages at Zirve University for approximately 6 months. The researcher observed whether the characteristics of blended learning were used properly in Schoology environment or not. According to Dziuban, Hartman and Moskal (2004), one of the characteristic features of blended learning is to increase interaction between student-instructor, student-student, student-content, and studentoutside materials. The process illustrated that both the teachers and the instructors used blended learning for interaction purposes. During the implementation process, Schoology provided teachers with an opportunity to interact with their students in every aspect, which was indicated as a positive advantage of Schoology in the survey conducted at the end of the implementation. According Bath 
Çepik, Ş., Gönen, K., \& Sazak, M. K. (2016). ELT instructors' attitudes towards the use of Blended Learning in tertiary level English language programs. International Journal of Human Sciences, 13(1), 1715-1730. doi:10.14687/ijhs.v13i1.3719

and Bourke (2010), another feature of blended learning is that the teachers can create online practice quizzes with an automatic marking functionality, which produces immediate and automatic results to the students. During the implementation, the instructors created weekly quizzes by using a built- in quiz creation feature of Schoology, which includes different types of questions. As soon as the students solved these quizzes, both the teachers and the students could see the results of the quizzes in the gradebook of Schoology. In this way, the teachers could track their students' success. Additionally, while using Schoology, the teachers created a wide range their own materials. As Gould (2003) states, classes offered in a blended learning format offer instructional materials in a wide range of formats, and this helps students who have different learning styles to benefit from different types of materials such as audio files, images, and videos. Looking at this feature of blended classes, it could be seen that during the implementation of blended learning the instructors were able to upload any kind of material related to the class onto Schoology, and the students benefited from these materials. Materials included PDF files, text files, presentation files, audio files, videos, images, and links related to the class.

Schoology provided all of the opportunities that an LMS program should have, and the teachers and the students at Zirve University used all these features with a combination of a traditional classroom environment, leading to a blended learning format.

\subsection{Research Question 2}

The second research question aimed to find out the thoughts of the instructors working at the School of Foreign Languages at Zirve University.

The second research question was:

\section{What are the attitudes of ELT teachers toward blended learning at Zirve University?}

In order to find an answer to this second research question, after the implementation of Schoology for 6 months, a survey was delivered to 35 randomly chosen instructors. Even though the aim of the survey was to find the attitudes of instructors toward blended learning, it also gave information about the technological background of the instructors, as well as their experience in computer usage. The survey consisted of 6 parts: demographic information; experience with educational technologies; attitudes toward blended learning; barriers that affect the adoption of blended learning; incentives of blended learning, to point out the challenges that the participants encountered before and during their blended learning experience, and to explore their ideas about whether blended learning should be used in language teaching and learning environment. The results of the survey showed that most of the participants liked the features of Schoology for blended learning purposes, but they pointed out the drawbacks of implementing blended learning at Zirve University. The negative responses of the participants resulted from mainly three themes: lack of teacher and student training, infrastructural problems, and lack of technological background. The results of the survey showed that most of the participants did not have enough technological training on blended learning, and they clearly indicated this in the qualitative part of the survey that the main reason they experienced difficulty in using Schoology was that there were not enough training for both the instructors and the students. Werth and Kellerer (2013) point out in the findings part of a study regarding the barriers affecting blended learning that "the training must not cease in the time prior to implementation, but should continue through the initial phases of implementation when struggles are likely greatest". 
Çepik, Ş., Gönen, K., \& Sazak, M. K. (2016). ELT instructors' attitudes towards the use of Blended Learning in tertiary level English language programs. International Journal of Human Sciences, 13(1), 1715-1730. doi:10.14687/ijhs.v13i1.3719

The finding of the study conducted by Werth and Kellerer is in line with the results of the study regarding the lack of training issue. If trainings for both the teachers and the students regarding the use of Schoology had been provided before and during the implementation of blended learning, the teachers and the students would not have experienced difficulty in using the LMS program.

Another major problem that was experienced by the instructors was reflected in both the quantitative and qualitative part of the survey. It was that the Internet coverage across the campus was poor, and this affected the implementation of blended learning in a negative way. Karunanayaka (2006) points out that limitations in IT infrastructure facilities, expensive bandwidths for the Internet connectivity, and high costs of developing infrastructure are some key elements that affect the implementation of computer-assisted learning. Since blended learning is a learning model delivered via the Internet, the instructors and teachers should be able to connect to the LMS program whenever they want, and it is possible with a strong Internet connection across the campus. Most of the participants indicated that in order to achieve a perfect blend, the teachers and the students should have a technological background, which prepares them for the use of computer and the Internet. This finding in this study is consistent with the findings of a study in the area of computer technology conducted by Mukti (2000), who found out that "teachers who were less knowledgeable perceived that they needed more skills and adequate knowledge to implement computer technology in the classroom".

\section{Implications for Further Studies}

In order to obtain more reliable results, trainings for both the instructors and the students should be given about blended learning before conducting a study. To strengthen the validity and the reliability of the results, the number of the participants should be kept as high as possible, and every age group should be included in the study. Before conducting a research regarding the use of technology in education, infrastructural problems like slow Internet connection should be eliminated. In order to obtain more clear data, the researcher can conduct a study with the participation of other faculty departments, if possible, and other educational institutions using an LMS program for blended learning purposes.

\section{REFERENCES}

AECT Definition and Technology Committee (2004). The meanings of educational technology. Retrieved http://www.indiana.edu/ molpage/Meanings $\% 20$ of $\% 20$ ET $4.0 . p d f \#$ search= $\% 22$ aect $\% 20$ committee $\% 20$ educational $\% 20$ technology $\% 22$

Aliağa M, \& Gunderson, B. (2000). Interactive Statistics. Saddle River, NJ: Prentice Hall Bath, D. \& Bourke, J. (2010). Getting Started With Blended Learning. Griffith Institution of Higher Education. GriffithUniversity Press. Boeree, C. G. (2005). Descriptive Statistics. Retrieved from http://webspace.ship.edu/cgboer/descstats.html

Handbook of blended learning: Global perspectives, local designs (pp. 550-567). SF, CA: Pfeiffer Publishing.

Chen, S., \& Lu, Y. (2013, June). The Negative Effects and Control of Blended Learning in University. In 2013 the International Conference on Education Technology and Information 
Çepik, S.., Gönen, K., \& Sazak, M. K. (2016). ELT instructors' attitudes towards the use of Blended Learning in tertiary level English language programs. International Journal of Human Sciences, 13(1), 1715-1730. doi:10.14687/ijhs.v13i1.3719

Copping, A. and Mellett, P, (2004). Blended Learning: An Appropriate Strategy for the Future Development of an Established International Distance Learning Course. In: International Forum on Open Learning, 2004-07-03 - 2004-07-07, Dunedin

Dziuban, C. D., Hartman, J. L., \& Moskal, P. D. (2004). Blended learning. EDUCAUSE Center for Applied Research Bulletin, 7(1), 12. Retrieved from http://www.educause.edu/ir/library/pdf/ERB0407.pdf.

Ellis, R. A., and Calvo, R. A. (2007). Minimum Indicators to Assure Quality of LMS supported Gould, T. (2003, June). Hybrid classes: Maximizing institutional resources and student learning. In Proceedings of the 2003 ASCUE Conference, 54-59.

Grgurovic, M. (2011). Blended learning in an ESL class: a case study. Calico Journal, 29(1), 100-117.

Hoic-Bozic, N., Mornar, Y, \& Boticki, I. (2009). A blended learning approach to course design and implementation. Education, IEEE Transactions on, 52(1), 19-30.

Karunanayaka, S. (2006). Computer assisted learning: a challenge for teachers and learners. Journal of the National Science Foundation of Sri Lanka, 34(2), 107-108.

Lynch, R., \& Dembo, M. (2004). The Relationship Between Self-Regulation and Online Learning in a Blended Learning Context. Retrieved from http://www.irrodl.org/index.php/irrodl/article/view/189/271

Marsh, D. (2012) Blended Learning: Creating Language opportunity for Language Learners. Cambridge University Press. New York. USA. Retrieved from http://www.cambridge.org/other files/downloads/esl/booklets/Blended-LeamingCombined.pdf

Marsh, D. (2013). An Introduction to Touchstone Blended Learning. Retrieved from http://www.cambridge.org/touchstoneblended/category/professional-development/ page $/ 2 /$

Merrow, J. (2012). Blended Learning, But To What End? | Taking Note. Retrieved from http:/ / takingnote.leamingmatters.tv/?p=5908

Mohammad, F. (2009). Blended Learning and the Virtual Learning Environment of Nottingham Trent University. DESE '09 Proceedings of the 2009 Second International Conference on Developments in eSystems Engineering, 295-299.

Mukti, N. A. (2000). Computer technology in Malaysia: Teachers' background characteristics, attitudes and concerns. The Electronic Journal on Information Systems in Developing Countries, 3(8), 1-13.

Patton M, Q., \& Cochran M. (2002). A guide to using Qualitative Research Methodology. Medecins Sans Frontiers, 2-34.

Sazak, M. (2014). The Attitudes of ELT Instructors toward Blended Learning at Zirve University (Master's thesis). Cag University Publ.

Schoology, Inc. (2013). wnw.schoology.com. Retrieved from https:// www.schoology.com/learningmanagement-system.php

Sharma, P. (2007). Try a blend that creates a new class of learning. Retrieved from http:/ /www.theguardian.com/education/2007/feb/16/tefll Sharma, P, \& Barett, B. (2007). Blended Learning: Using technology in and beyond the language classroom. Oxford: Macmillan.

Singh, H., \& Reed, C. (2001). A white paper: Achieving success with blended learning. Centra Software. 
Çepik, Ş., Gönen, K., \& Sazak, M. K. (2016). ELT instructors' attitudes towards the use of Blended Learning in tertiary level English language programs. International Journal of Human Sciences, 13(1), 1715-1730. doi:10.14687/ijhs.v13i1.3719

Tang, X., \& Pan, Q. (2008, November). Study on the Application of Blended Learning in the College English Course. In Future Information Technology and Management Engineering, 2008. FITME'08. International Seminar on (pp. 133-136). IEEE.

Valiathan, P. (2002). Blended Learning Models. Retrieved from http:/www. pumimavaliathan.com/readings/Blended-Learning-Models-2002ASTD.pdf

Werth, E., Werth, L., \& Kellerer, E. (2013). Transforming K-12 Rural Education

through Blended Learning: Barriers and Promising Practices. iNACOL. Retrieved from http://www.inacol.org/cms/wp-content/uploads/2013/10/iNACQL-TransformingK-12Rural-Education-through-Blended-Learning.pdf

Whittaker, C. (2011). Blended Learning in English Language Teaching: Course Design and Implementation. British Council.

Yin, R. K. (1984). Case Study Research: Design and Methods (1st ed ). Beverly Hills, CA:Sage Publications. 